\section{Story Telling is Not Fibbing!}

\section{Cecil Hamilton}

W Te all have a favourite story or stories that we have filed away in our memory banks. These may be fables, fairy tales, stories of family origins as told by an elderly relative or be even a naughty tale picked up from one of our friends and retold to a few of our buddies. When one shares one's favourite story one becomes a storyteller. This art of passing on information orally dates back to a much earlier time. The purpose of this article is not to deal with the development of oral language and the sharing of information around a smoldering fire but rather to deal with storytelling as an essential building block in the reading process.

\section{Spreading wings}

Young children absorb stories like sponges and interpret much from their environments. Children acquire spoken vocabulary at a tremendous rate. There are about 44 speech sounds in the English language that most children use by age 3 . Piaget instructs us that children construct meaning through their experiences. In an environment where talking is encouraged, where being read to on a regular basis is routine and where discussion is a part of story time together, children are bound to spread their wings! The role of the teacher is to make sure that those wings continue to strengthen. What better way to do this than through story telling?

Most pre-school and elementary teachers do a superb job of sharing books with their students. Listening to a well read story captures the imagination of the lis- tener. Children love to participate in story reading and storytelling.

Teachers know that this is a good way to introduce children to the sounds of language contained in words and sentences and is an excellent lesson delivery model for introducing new vocabulary into a child's language repertoire. It is also a way of having children enjoy stories that they cannot yet read independently and is a means of introducing young people to the works of authors, poets, and song writers. Teachers know that storytelling and story reading provides opportunities for teachers to instill good listening skills and how to recognize the structure of a story, i.e. settings, characters and plot. Guiding children to predict aspects of a story is a necessary part of reading comprehension. Teachers direct this listening through careful questioning. It is known that listening to a story being read aloud is beneficial to comprehension. It follows that telling a story must have the same value?

\section{Re-building and Retelling}

Any story can be retold rebuilt and or adapted for telling and sharing. In doing so, the concepts and structures of story building can be emphasized and taught.

To be able to re-tell a story implies that a student understands the foundations of story building and thus it can be assumed that the child is understands elements of language construction important in communication. When a child can move beyond repeating a story and is able to create and tell a story of his/her own making it indicates that the schema of a story is in place. This would be a strong indicator that a child is ready for reading instruction--whatever method may be used.

As teachers we know that re-telling is an excellent way to measure comprehension. With young learners it makes sense to have them re-tell short, simple stories. A good way to begin is to encourage them to re-tell stories you have shared with them. It is essential that early in the process children understand that stories have a beginning, middle and an end. Where does the story happen? Who is in it? What do the characters do?

As children become comfortable with the story telling mode you can increase the parameters. These may include, for example, varying the tone of voice-loud or soft, varying the volume, the rate of speaking, introducing characters by changing how you move, stand, etc., by using your arms or gestures, involving the listeners by having them repeat a refrain or provide sound effects, etc. Re-telling with the use of simple props is a worthwhile approach.

Skillful teachers know that accurate re-telling must be modeled. I can hear teachers saying, "I can't do that!" But, I say of course you can. Who better than you, teacher, to model this re-telling? Children will pattern what you do because they trust you.

There is a basic set of guidelines to follow as you prepare to become a storyteller.

- Select a simple story for your first time.

- Read it several times. You don't have to memorize it.

- Re-tell it to your mirror. Remember the old adage Practice makes perfect?

- Just keep the main events in their proper sequence. 
- Use a prop if you feel comfortable doing so.

If you are reluctant or uncertain try telling a nursery rhyme. It is likely that you could be Little Miss Muffet quite successfully. If you give it some thought, this could be a short, sweet little production. Use your voice, use gestures, and maybe even a toy spider. Storytellers do their best work on their feet. Use fables or other short, familiar stories. It is possible to get lots of mileage out of old favourites such as The Three Billy Goats Gruff, Goldilocks and the Three Bears, etc. The more you tell stories, the better you will feel about it and the better you will become at it. You can guarantee your own success by keeping the approach simple.

Story telling is similar to creative drama. If you think about it, story telling and drama do have much in common. As a storyteller, you take on a role and by the use of your voice, facial expressions, eye contact with the listeners and use of gestures; you are able to communicate the story to your audience.

\section{Why should you tell stories to your children?}

Story telling brings listeners together in a common experience. There is a contact, a connection, made between the listeners and the teller. The audience becomes a part of the story and forms an empathy with a character or characters. As a storyteller you have the power to expose your audience to a variety of literary genres. Story telling is an excellent way of motivating youngsters to read and write. Young children will pattern what they hear. Listening and speaking vocabularies develop through stories heard and re-told. Listening to a good story whets imagination and builds images inside the head. Good sto- ries, told well, are great entertainment too!

\section{"Through story-telling children can become actively involved in the story experience." (Norton, 2004 p. 225)}

Listening to a story read or told by an adult should ensure that children are involved in making a connection with the author's story. This connectedness is what comprehension is all about. Graph phonics, syntax, semantics are all valuable parts of becoming a good reader but they must work together and not as isolated components.

Once you have made the initial plunge into the wonderful world of story telling, make it a point to tell a story at least once a week. Eventually you will be able to put your children into small groups and let them re- tell the story you have just read or told.

Use the talking stick idea to ensure that everyone has a turn at adding details. To comprehend is to grasp an idea. The ability to tell a story so that listeners grasp the theme is a valuable teaching/ learning tool.

"The most important type of reading comprehension is comprehending what reading really is."

(Hamilton and Moore, 1998, p.110)

Before reading means anything to children they must have a schema about reading. Just what is this thing called reading? It is certainly more than phonics in isolation or word lists without sentences. Syntax, semantics and phonics are all clues to help the reader make sense of print. Primary teachers know when and how to help children make those connections.

Teachers understand the value of using predictable text with emerging readers. Such patterned literature allows children to be readers at an early stage. Stories by Bill Martin Jr., Eric Carle and Paul Caldone, to name a few, can be found in most classrooms. These stories are good for reading to children, for placement in the book center and also for re-telling. Being read to and having stories told are essential to the development of good listening habits.

Listening is an important language mode and certainly provides a basis for growth in all of the other arts of language. A necessary pre-reading step is to be able to hear the words in sentences and to use those ideas in telling the story aloud to peers, the class, a parent or the teacher.

\section{Structured Listening Activity or S.L.A.}

This is a strategy commonly used by many teachers. It is a procedure that helps to direct children's listening. A key component of this strategy is directed discussion where children are encouraged to predict and verify their predictions (Hamilton and Moore, 1998, p. 7).

The role of prediction is an important one. When you read to your children, you are providing an experience with a whole story. Reading comprehension builds on listening comprehension as children are guided to hear how a story develops and to practice re-building a story by telling it aloud. Allowing discussions about the story and encouraging oral re-telling by the listeners provides a language-rich opportunity for your children to expand their vocabularies and to begin to build an idea of what a story is. Too often, we, as teachers, want to rush to a paper and pencil task that effectively cuts down the oral language growth by a considerable amount. Somehow we have be- 
come convinced that comprehension is aligned with putting it down on paper. Oh, those curriculum expectations!

\section{Telling stories helps practice makes perfect}

Children's re-telling of a story is a valuable assessment tool. How a story is told and the content used gives you, the teacher, a valuable insight into how well a child comprehends the story.

- Does the child use the vocabulary of the story?

- Is the story told in a logical sequence?

- Does the child use connected, grammatically correct sentences appropriate to his/her age?

- Is there a rubric shaping up here or would a simple checklist do?

While retelling a standard story based on an objective described in a curriculum resource and identified by a rubric which outlines the ebb and flow of the assessment profile is important, one should not forget that encouraging children to tell stories simply for fun helps to make them feel comfortable in the telling and encourage creativity and literacy.

A good storyteller does not have to rely on props but may choose to enhance a story by their use. As a beginning teller of stories you might want to use a felt board or a series of pictures on a flip chart. Some teachers use objects from the story or a series of pictures to build the story. Chalk talks are an effective way of illustrating a story as you tell it. You don't have to be a Rembrandt! Stick figures are quite adequate.

Before you know it you will be wearing a storytelling apron or a story backpack or using a story box from which you pull objects related to your story. Sometimes using a series of hats (one for each character) can enhance a story. The possibilities are limitless. Just let your imagination go!

The internet is a wonderful source for "How To" ideas. Here is a suggested site for your perusal.

http://www.eldrbarry.net/roos /eest.htm

Let's not for one minute think that storytelling is purely a primary grade activity. Not so! Children in the Junior and Intermediate-Senior Divisions should be provided with opportunities to tell stories too. It would be excellent practice of those specific expectations listed for Reading and Oral and Visual Communication in the Ontario Curriculum.

Many schools, I know, have Oral Communications Festivals (prepared speeches by any other name). Wouldn't it be a wonderful venture to hold a Storytelling Festival? This might happen in a school in a particular division or across an entire school board district. Perhaps the entire Grade
Four division could participate or perhaps on a grander scale all of the Junior Division classes. Teachers are wonderfully creative and innovative people. I am willing to bet that it could be done.

Give it a try!

\section{References}

Hamilton, Cecil and Wm. H. Moore. 1998. Are You Listening? Hamilton, ON: Tree House Press Inc.

May, Frank B. 1998. Reading As Communication, 4th Edition. Toronto, ON: Prentice-Hall of Canada Inc.

Norton, Donna E. 2004. The Effective Teaching of Language Arts. 6th Edition Upper Saddle River, NJ: Pearson Prentice Hall.

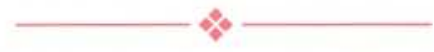

In addition to being a retired principal from the former Wentworth County Board of Education, $\mathrm{Cec}$ Hamilton was a

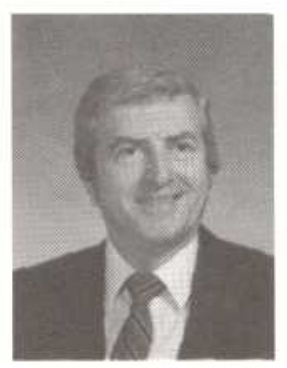
lecturer/instructor in Language Arts \& Reading for many years at Brock University. Cec serves on the board of Directors of Westfield Heritage Village where he has been a long-time volunteer and historic interpreter. He does in-role presentations, eg. the early schoolmaster, the minister in the church on site and recently played Bishop John Strachan. He really enjoys reading to young children and older ones. Cec also takes part in many amateur dramatic productions.

All acts of language are interrelated, but story should hold a special place in a child's development. Writing [and telling] activities that promote story, interpret story, alter story, or generate other stories must be true learning situations for both the child as reader, the child as writer, [and child as teller]. The place called school is an excellent place to foster storytelling as cultural link to our ancestral past, our lived present and our [unforetold] future. We are all part of the storytelling world that we inhabit from birth to death".

Adapted from Barton and Booth, Stories in the classroom 1990, Pembrook. 